\title{
EFFECT OF HEATING, MIXING AND DIGESTER TYPE ON BIOGAS PRODUCTION FROM BUFFALO DUNG
}

\author{
Abdel-Hadi' ${ }^{1}$, M. A. and Abd El-Azeem², S. A. M.
}

\begin{abstract}
Egypt has 3.43 million head buffalo and they produce about 3.5 millionton/year of dung as air-dried material. The uncontrolled handling and storage of dung causes loss of organic matter, environmental pollution, methane emissive and a bad smell. The anaerobic digestion is one of the common technologies used for recycling organic wastes. Laboratory bench-scale biogas digester 22 liter capacity and 17 liter digestion volume (3 horizontals and 3 verticals type) were used for batch anaerobic digestion system of 95 day hydraulic retention time of buffalo dung 6.30 OTS\% to study the effect of temperature, mixing and digester type on biogas production and methane content. The obtained results show that the biogas produced ranged between 104.7 to $468.1 \mathrm{~L} \mathrm{~kg}^{-1}$ organic total solid (OTS) while methane yield ranged between 69.2 to $284.1 \mathrm{~L} \mathrm{~kg}^{-1}$ OTS. The highest biogas yield was observed in vertical digester (468.1 $\mathrm{L} \mathrm{kg}^{-1}$ OTS) compared to horizontal digester $\left(353.1 \mathrm{~L} \mathrm{~kg}^{-1}\right.$ OTS) in the cases of mixing and heating treatments. Meanwhile, the horizontal digester produced biogas (293.2 $\mathrm{L} \mathrm{kg}^{-1}$ OTS) more than vertical digester (179.0 $\mathrm{L} \mathrm{kg}^{-1}$ OTS) without mixing under room temperature. Similarly, the degradation percent of buffalo dung (expressed as organic carbon degradation, \%) was increased in vertical digester compared to horizontal digester with mixing and temperature treatments. Consequently, the biogas and methane production were positively correlated with the temperature. Therefore, the maximum biogas yield was recorded in vertical digester with heating and mixing conditions. Maximum enhancement in biogas production over the control could be well correlated with maximum reduction in OTS and C/N ratio of buffalo dung manure.
\end{abstract}

${ }^{1}$ Assist. Prof. of Dep. Ag. Eng. and ${ }^{2}$ Assist. Prof. of Dep. Soil and Water, Fac. of Ag., Suez-Canal U., 41522 Ismailia, Egypt. 
Therefore, we concluded that the amount of biogas production was not only depending on the type of digester but also affected by other parameters, i.e. mixing and heating conditions of the digester. The quantitative variations in biogas production were related with OTS, $C, N$ and $C / N$ ratio of the buffalo dung used.

Keyword: Anaerobic digestion, Batch fermentation, Biogas and methane production, Buffalo dung

\section{INTRODUCTION}

naerobic digestion of organic matter with a simultaneous
production of biogas is an environmentally attractive way for the
treatment of organic waste. Egypt has 3.43 million head buffalo (FAO, 2001) and they produce about 3.5 million-ton/year of dung as airdried material. The uncontrolled handling and storage of dung causes loss of organic matter, pollution and odour problems (Reinecke et al., 1992). Hamdy (1998) mention that about $60 \%$ of Farmyard wastes are used as fuel by direct burring in low efficiency burners and $20 \%$ of the animal wastes are used as organic fertilizer and the rest is lost in handling. Viesturs et al. (1995) mentioned possible technologies for biomass conversion with energy production, such as thermal processes, hydrolysis, enzymatic hydrolysis and with microorganisms (aerobic and anaerobic). The choice of a certain technique depends on composition of the material as well as the advantages and the drawbacks of such technique. The thermal processes, chemical hydrolysis and enzymatic reactions are not considered for the complexity, high cost and high- tech of such technologies to be applied on farm scale.

Biogas is a form of energy produced when organic material such as buffalo dung is left over from agriculture wastes; also it is a major source of the substrate in a biogas plant. Nowadays, the use of biogas has spread from small farms to big animal farms. It is expected that biogas will be a significant source of energy in the future to preserve the environment, solve the pollution problem and to promote better health to agriculture and community. After animal excrement had been fermented in the biogas 
plant, it becomes a good quality and odorless substrate, which is better than fresh manure in improving the soil for the agriculture. During this process, the important plant nutrients, such as nitrogen, potassium, phosphorous and calcium present in feed material are converted into forms that are much more soluble available to plants than those in the parent compounds (Ndegwa and Thompson, 2001). The buffalo discharge was ranged between 8 to $12 \mathrm{~kg} /$ animal/day (Rofiqul et al., 2006), $15 \mathrm{~kg} / \mathrm{animal} /$ day (FAO, 2005) and $16.4 \mathrm{~kg} / \mathrm{animal} /$ day (DGS, 2006). The average compositions of fresh dung are $20.5 \%$ total solids (TS) and its contents of OTS $17.45 \%$ (Shilpkar et al. 2007). Nanda and Nakao (2003) pointed that one $\mathrm{kg}$ fresh buffalo dung produces $0.037 \mathrm{~m}^{3}$ of biogas. On the other hand, one kg OTS from buffalo dung produces $0.2-0.26 \mathrm{~m}^{3}$ of biogas (DGS, 2006).

Lehtomäki et al. (2007) reported that the ultimate methane yield can be determine in a batch experimental when the biomass fibrously and strongly analyzable. The contents are continuously mixed, which facilitates good distribution of the nutrients and bacteria (Vandeviviere $\boldsymbol{e t}$ al., 2002). The organic material is loaded in the digester and digested for the period for 30-180 days hydraulic retention time, which depending on ambient temperature and other factors such as mixing and total solids. This fermentation can be conducted at normal solids content of 610 TS\% (Marchaim, 1992).

köttner (2003) reported that the process of anaerobic digestion is running at its optimum temperature range of 25 to $38^{\circ} \mathrm{C}$ (mesophilic conditions), the latter prefer temperatures in the range of $38^{\circ} \mathrm{C}$ are greater stability of digestion process, easier to control and utilized in about 95 percent of all digesters. Furthermore, a mesophilic treatment at $38^{\circ} \mathrm{C}$ reportedly destroys $99.9 \%$ of pathogens (Erickson, et al., 2004). Other researchers suggested that an increase in the temperature resulted in a reduction of the biogas yield, due to the increased inhibition of free ammonia $\left(\mathrm{NH}_{3}\right)$ which increases with increasing temperature (Angelidaki and Ahring, 1994; Hansen et al., 1999).

Kalia and Singh (1998) and (Shilpkar et al., 2007) pointed that the $\mathrm{C} / \mathrm{N}$ ratios of fresh cattle dung and fresh buffalo dung are 38.1 and 29.0, respectively. Kayhanian and Hardy (1994) reported that $\mathrm{C} / \mathrm{N}$ ratios 
between 25 and 30 as being optimal for anaerobic digestion. However, some investigators argue that the $\mathrm{C} / \mathrm{N}$ of approximately from 16.8 to 18 is optimal for methanogenic performance if poorly degradable compounds such as lignin are taken into account (Kivaisi and Mtila, 1998).

Dolfing (1992) suggested that very rapid mixing disrupts the structure of flocks in completely mixed reactors, thereby disturbing the dystrophic relationships between organisms. An intermediate degree of mixing was found to be optimal for substrate conversion (Smith et al., 1996).

The present study aims to investigate the biogas and methane production from buffalo dung under different parameter of mixing, temperature, digester type (i.e. vertical or horizontal) using lab bench- scale batch system. The experiment was carried out for a period of 95 days. Biogas production was measured at $24 \mathrm{hr}$. interval by water displacement method with corresponding environmental temperature, while quantity of methane was checked using $40 \%$ potassium hydroxide (Okeke and Ezekoye, 2006).

\section{MATERIALS AND METHODS}

\section{Bench-scale biogas digester}

A bench-scale of cylindrical biogas digester (horizontal and vertical type) are shown in Figs. (1) and (2). They are 3 horizontals biogas digesters and 3 verticals biogas digesters, were constructed at the Agricultural Engineering Department, Faculty of Agriculture, Suez-Canal University. Each digester was fabricated from galvanized steel sheet of $1.5 \mathrm{~mm}$ thickness, $45 \mathrm{~cm}$ length and $25 \mathrm{~cm}$ diameter with total capacity of 22 liters and digestion volume of 17 liters and it has a PVC inlet and outlet tube of $50.8 \mathrm{~mm}$ ( $2 \mathrm{in}$.) diameter for feeding by organic wastes and rejecting the digested materials. To follow up the digestion processes, orifice for releasing the produced gas was provided to the digester and another for the $\mathrm{pH}$-temperatures measurements. Released gas volume was collected in gasholder and determined by using the wetted displacement with a previously calibrated scale in liter. 


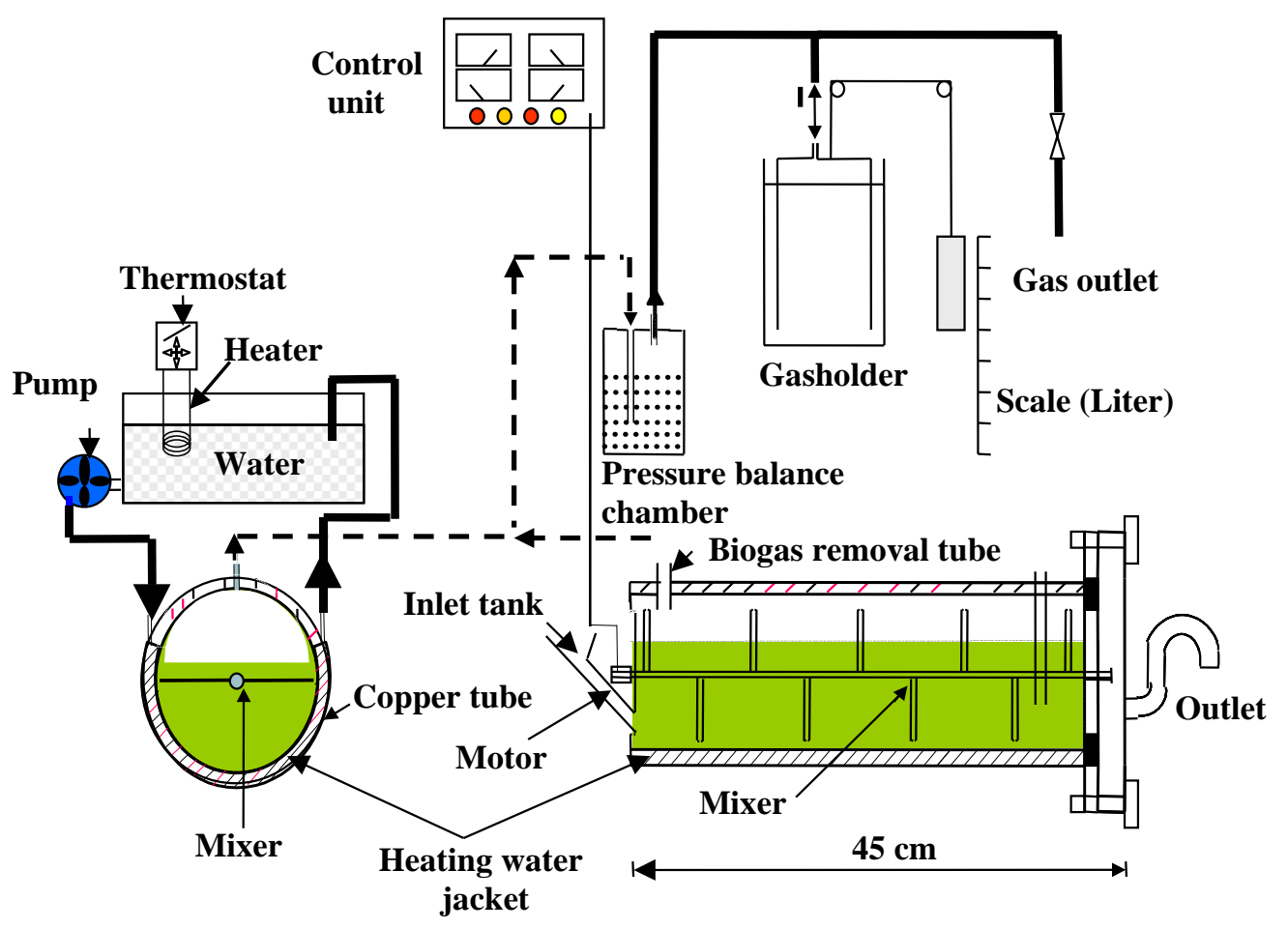
A: Digester cross section illustrates the heating cycle
B: Longitudinal section illustrates
the other components

Figure (1): Schematic diagram of horizontal bench-scale biogas digester.

A hasp mixer was mounted with the biogas digester; and adjusted automatically at 2 minute each one half hour, meanwhile a thermostatic heating unit provided the digester with a pump to adjust and temperature selector.

The bench-scale digesters were used to measure and detect the suitable operating conditions to obtain the ideal biogas production with high methane ratio for the used buffalo dung 8.96 TS\% and 6.30 OTS\%. 


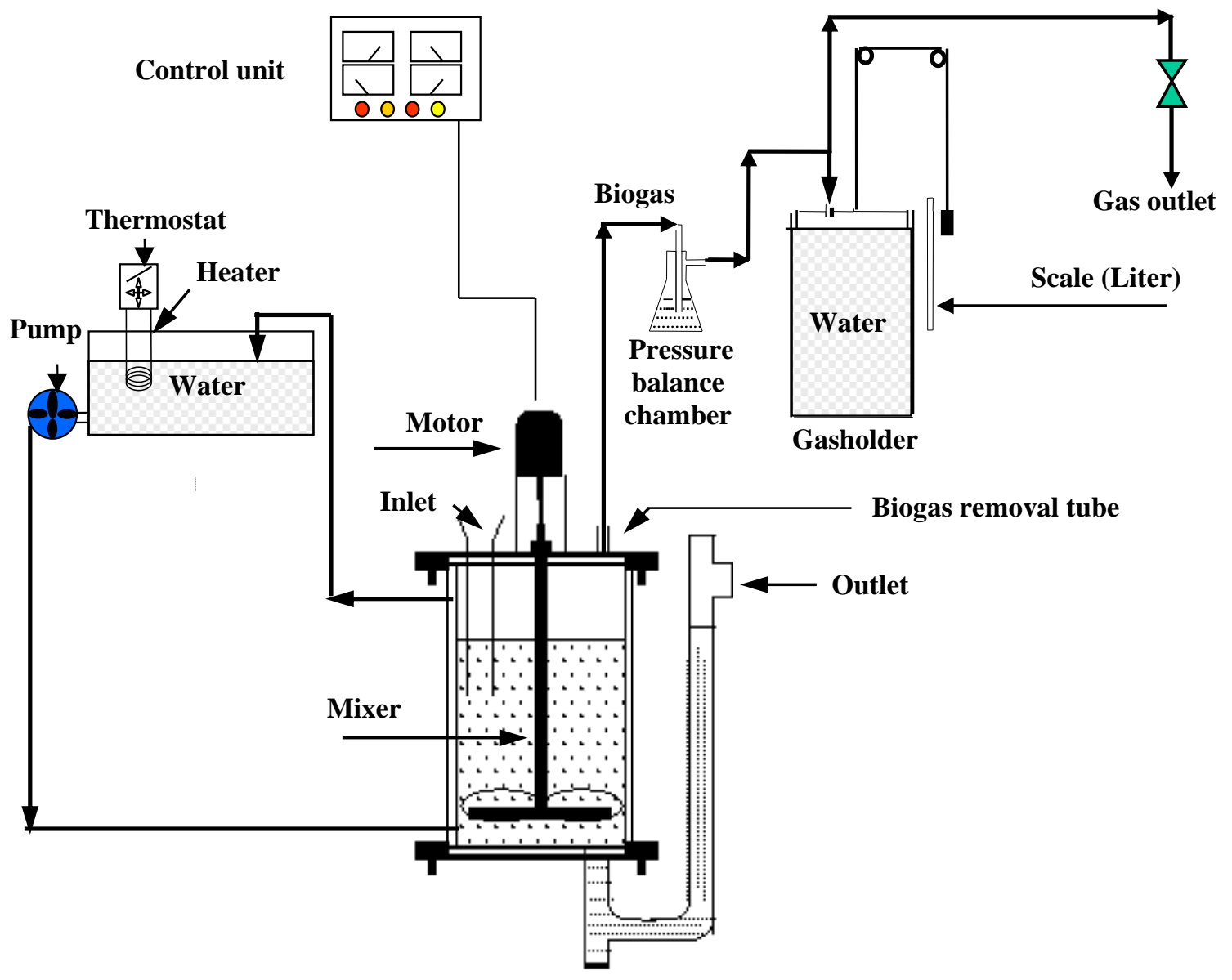

Figure (2): Schematic diagram of vertical bench-scale biogas digester.

The temperature of buffalo dung mixture was adjusted within the mesophilic region $\left(38{ }^{\circ} \mathrm{C}\right)$. A thermostatic electrical heater and a centrifugal pump, operated by 90 -Watt motor, were assembled with an insulated water tank to form the heating unit beside the close cycle serpentine as shown in Fig. (1, A). Copper tube of $7.5 \mathrm{~m}$ length, $(9.53 \mathrm{~mm}$ and $8.3 \mathrm{~mm}$ outer and inner diameters) serpentine was coiled around the digester and was insulated using $25.4 \mathrm{~mm}$ thick Polystyrene slabs (Foam) to create a stable temperature water jacket around the digester. 


\section{Analytical methods and Instrumentation}

\section{Total solids (TS) and organic total solids (OTS) determination}

The total solids percentage (TS\%) and its contents of organic total solids percentage (OTS\%) for the fresh dung substance also at the outlet orifice were determined in this study. Samples of 80 to 100 grams were used, dried for 24 hours at $105{ }^{\circ} \mathrm{C}$ then the samples total solids were weighted using Ohaus ${ }^{\circledR}$ digital balance till reaching the equilibrium. To determine the organic total solids contents percentage in the dry solids of each sample. The dry solids were dried at $560{ }^{\circ} \mathrm{C}$ in muffle oven; the TS\% and OTS\% were calculated from the following formula (DEV, 1971):

$$
\begin{gathered}
T S \%=\frac{M_{T S}}{M_{f}} \times 100 \\
O T S \%=\frac{M_{a s h}-M_{T S}}{M_{f}} \times 100
\end{gathered}
$$

Where: $\mathrm{M}_{f}$ is the fresh mass, $M_{T S}$ is the mass of total solids and $\mathrm{M}_{a s h}$ is the ash mass

Meanwhile, the organic total solids (OTS) mass in $\mathrm{kg}$ was determined from Wittmaier (2003)

$$
\text { OTS }=\mathrm{M}_{f} \times \mathrm{OTS} \%
$$

\section{Daily biogas production}

During the batch fermentations the released gas volume in liter everyday was measured laboratory using the wetted displacement with a previously calibrated scale are shown in Figs. (1) and (2).

\section{Methane percentage}

The daily released biogas was fractioned in a percentage i.e. methane and $\mathrm{CO}_{2}$ percentage using the Potassium hydroxide $40 \%$ (Okeke and Ezekoye, 2006). 


\section{Daily methane yield}

Daily volume of the methane yield in liter was determined by the multiplication of the daily biogas yield in liter (which was determined from the previous step) by the same daily percentage of the methane.

\section{Degradation ratio}

The degradation ratio of organic matter was determined each 5 days along the hydraulic retention time (HRT) 95 day and averaged. It was determined as the percentage of the difference between the OTS from the beginning of the experiments and after five days divided by the OTS at the beginning according to the following equation:

$$
D R, \%=\frac{\text { OTS at the begining }- \text { OTS after } 5 \text { days }}{\text { OTS at the begining }} \times 100
$$

\section{Digester specific of biogas and methane production}

The digester specific of biogas and methane produced was determined in liter/liter.day. The amount of the biogas obtained along the HRT was collected and divided on the period of the HRT to obtain the average daily gas volume in liter/day, which was divided by the digestion volume in liter to obtain the average digester specific gas yield in L/L.d.

\section{Temperature and $\mathrm{pH}$}

The temperature also the $\mathrm{pH}$ value of the buffalo dung solution inside the bench-scale digesters were regularly daily measured using Jenway $\mathrm{pH}$ hand held meter model $370 \mathrm{pH} / \mathrm{mv}$. The temperature of buffalo dung inside digester was adjusted within the mesophilic region $\left(38^{\circ} \mathrm{C}\right)$.

\section{Statistical analysis}

The SPSS statistical package, version 10.0 (SPSS Inc., Michigan, USA), was used for the statistical analysis. Bivariate correlations analysis was done to establish the significance of differences in both biogas and methane yield as dependent parameters and $\mathrm{pH}$ and digester temperature as independent parameters. 


\section{RESULTS AND DISCUSSIONS}

\section{Biogas and methane production}

Biogas, methane yield and percentage were recorded in two type anaerobic digester under the different parameters of temperature and mixing at definite interval throughout the lab experiment. The results show that the biogas yield in vertical digester was between 104.7 to 468.1 $\mathrm{L} \mathrm{kg}^{-1}$ OTS while the methane yield ranged between 69.2 to $284.1 \mathrm{~L} \mathrm{~kg}^{-1}$ OTS (Table 1). Concerning the horizontal digester, results in Table (1) show that the biogas and methane yield were increased with stirring and increasing temperature comparing to the without mixing under room temperature as a control. It was noticed that the biogas and methane yield were only decreased with mixing treatment. Consequently, the biogas and methane yield was positively correlated with temperature. The same trend was observed in the vertical digester. On the average, the produced biogas during the experiment contained 64.8 and $62.8 \%$ methane in the cases of both horizontal and vertical digesters, respectively. The average of methane percentage was fluctuated in two examined digesters under mixing and heating treatment. The highest percentage of methane (66.2 and $66.1 \%$ ) was recorded in horizontal and vertical digester in the cases of mixing with heating and mixing without heating treatments respectively. Since the highest amount of biogas yield was observed in vertical digester (468.1 $\mathrm{L} \mathrm{kg}^{-1}$ OTS) compared to horizontal digester (353.1 $\mathrm{L} \mathrm{kg}^{-1}$ OTS) in the cases of mixing and heating treatments respectively. On the other hand, the horizontal digester produced biogas yield (293.2 $\mathrm{L} \mathrm{kg}^{-1}$ OTS) more than vertical digester (179.0 $\mathrm{L} \mathrm{kg}^{-1}$ OTS) without mixing and heating. Therefore, we suggested that the amount of biogas yield was not only depending on the digester shape but also depending on the mixing and heating the raw material. In this regard, many previous researches have suggested that the biogas production during anaerobic digestion is related to temperatures. However, different results have been reported (Hansen $\boldsymbol{e t}$ al., 1999 and Chae $\boldsymbol{e t}$ al., 2008). El-Mashad et al. (2004) suggested that the digestion temperature has an influence on the ultimate biogas and methane yield as well as the methane content. In the mesophilic temperature range, $25-35^{\circ} \mathrm{C}$, the better biogas and methane were produced. In addition, the biogas yield did not linearly 
increase with increasing temperature. Other researchers suggested that an increase in the temperature resulted in a reduction of the biogas yield, due to the increase inhibition of free ammonia $\left(\mathrm{NH}_{3}\right)$ which increase with increasing temperature (Angelidaki and Ahring, 1994; Hansen et al., 1999)

Table (1): Biogas and methane production under the different temperature and mixing treatments of the vertical and horizontal digesters

\begin{tabular}{|c|c|c|c|c|c|}
\hline $\begin{array}{c}\text { Digester } \\
\text { shape }\end{array}$ & Treatments & $\begin{array}{l}\text { Temperature } \\
{ }^{\circ} \mathrm{C}\end{array}$ & $\begin{array}{c}\text { Biogas, } \\
\mathrm{L} \mathrm{kg}^{-1} \text { OTS }\end{array}$ & $\begin{array}{l}\text { Methane, } \\
\mathrm{L} \mathrm{kg}^{-1} \text { OTS }\end{array}$ & $\begin{array}{c}\text { Methane**, } \\
\%\end{array}$ \\
\hline \multirow{3}{*}{ 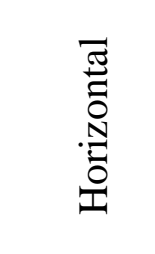 } & Control* & 24.7 & 293.2 & 190.0 & 64.8 \\
\hline & $\begin{array}{l}\text { Mixing under room } \\
\text { temperature }\end{array}$ & 25.1 & 171.2 & 109.0 & 63.7 \\
\hline & Heating and mixing & 38.7 & 353.1 & 233.7 & 66.2 \\
\hline \multirow{3}{*}{ 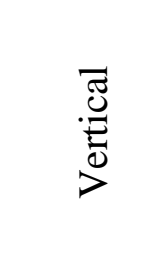 } & Control* & 24.9 & 179.0 & 112.4 & 62.8 \\
\hline & $\begin{array}{l}\text { Mixing under room } \\
\text { temperature }\end{array}$ & 24.5 & 104.7 & 69.2 & 66.1 \\
\hline & Heating and mixing & 38.1 & 468.1 & 284.1 & 60.7 \\
\hline
\end{tabular}

*: Under room temperature

**: Mean values of temperature and methane percentage

\section{Effect of mixing and digester type on the digester specific biogas yield}

The effect of mixing on anaerobic digestion of buffalo dung was evaluated in bench scale digester at $38{ }^{\circ} \mathrm{C}$. Because mixing duration and intensity affect on the performance of anaerobic digestion are contradictory, we used in this study the stable mixing system (2 minute each one half hour). The effect of digester type was evaluated on biogas yield under the different mixing and heating treatments. The digester specific biogas yield was greatly varied in both vertical and horizontal digester under mixing or heating. Fig. (3) shows that the digester specific 
biogas yield L/L.d was increased by $70 \%$ in horizontal digester compared to vertical digester under the room temperature. The same trend was observed in case mixing treatment under room temperature. The digester specific biogas yield L/L.d by horizontal and vertical digester type in case mixing treatment under room temperature less than in case without mixing under room temperature as a control. The digester specific biogas yield was ranged between $0.06 \mathrm{~L} / \mathrm{L} . \mathrm{d}$ in case mixing treatment under room temperature vertical digester type to $0.27 \mathrm{~L} / \mathrm{L} . \mathrm{d}$ in case of mixing plus heating treatment vertical digester type.

The results indicated that mixing treatment decreasing digester specific biogas yield in both digester type. The importance of mixing in achieving efficient substrate conversion has been reported by several researchers (Stroot et al., 2001; Kim et al., 2002; Karim et al., 2005; Vavilin and Angelidaki, 2005; Vedrenne et al., 2007). The main factors affecting digester mixing are the mixing strategy, intensity, duration and mixer location in the system. However, the effect of mixing duration and intensity on the performance of anaerobic digesters are contradictory. Adequate mixing was shown to improve the distribution of substrates, enzymes and microorganism throughout the digester (Lema $\boldsymbol{e t}$ al., 1991) whereas inadequate mixing was shown to result in stratification and formation of floating layer of solids (Chen et al., 1990). In general, the obtained results show that the mixing treatment under room temperature decrease the biogas yield (Table 1) and digester specific biogas yield L/L.d Fig. (3). These results agree with Kaparaju et al. (2007) who found that the vigor mixing would result in delaying and lowering methane production. 


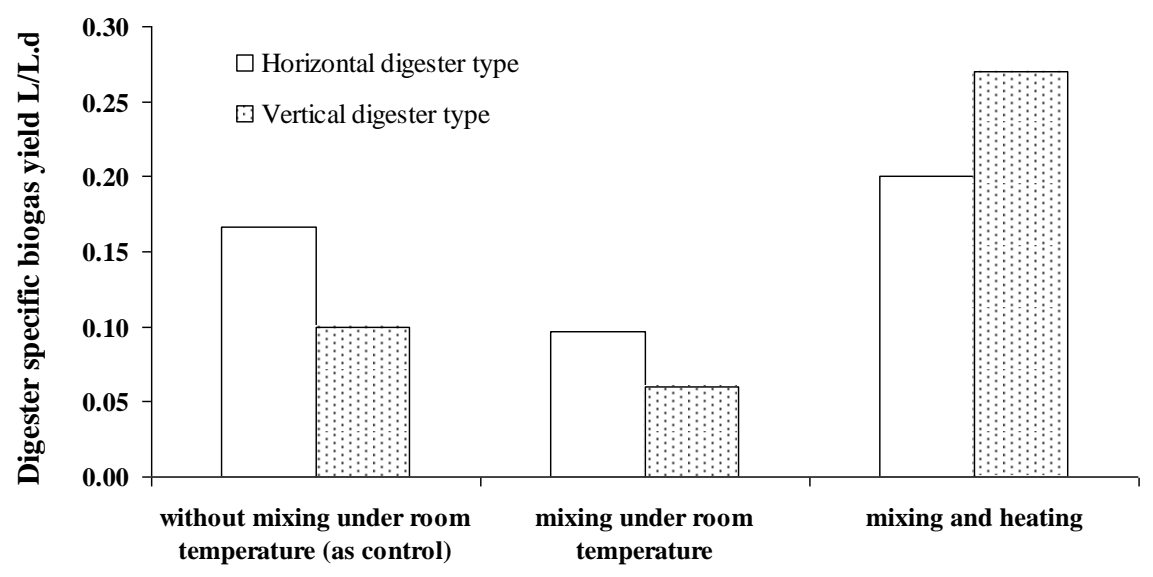

Figure (3): Digester specific biogas yield L/L.d.

The measured $\mathrm{pH}$ values for the anaerobic digestion of buffalo dung in vertical and horizontal digesters at experimental intervals are shown in Fig. (4). The $\mathrm{pH}$ values in the horizontal digester with mixing and heating treatments are slightly higher compared to under room temperature without mixing as a control. In addition, $\mathrm{pH}$ values not greatly affected by mixing in both vertical and horizontal digesters compared to control. The $\mathrm{pH}$ values were ranged from 6.98 to 7.24 and from 7.07 to 7.28 in horizontal and vertical digesters, respectively.

The $\mathrm{pH}$ is known to influence enzymatic activity, because each enzyme has a maximum activity within a specific and a narrow $\mathrm{pH}$ range. The $\mathrm{pH}$ of the digestion liquid material and its stability as well comprises an extremely important parameter, since methanogenesis only proceeds at high rate when $\mathrm{pH}$ is maintained in the neutral range. Most methanogenic bacteria function optimally at $\mathrm{pH} 7$ to 7.2 , and the rate of methane production declines at $\mathrm{pH}$ values below 6.3 or exceeding 7.8 (Bitton, 1994; Van Haandel and Lettinga, 1994). 

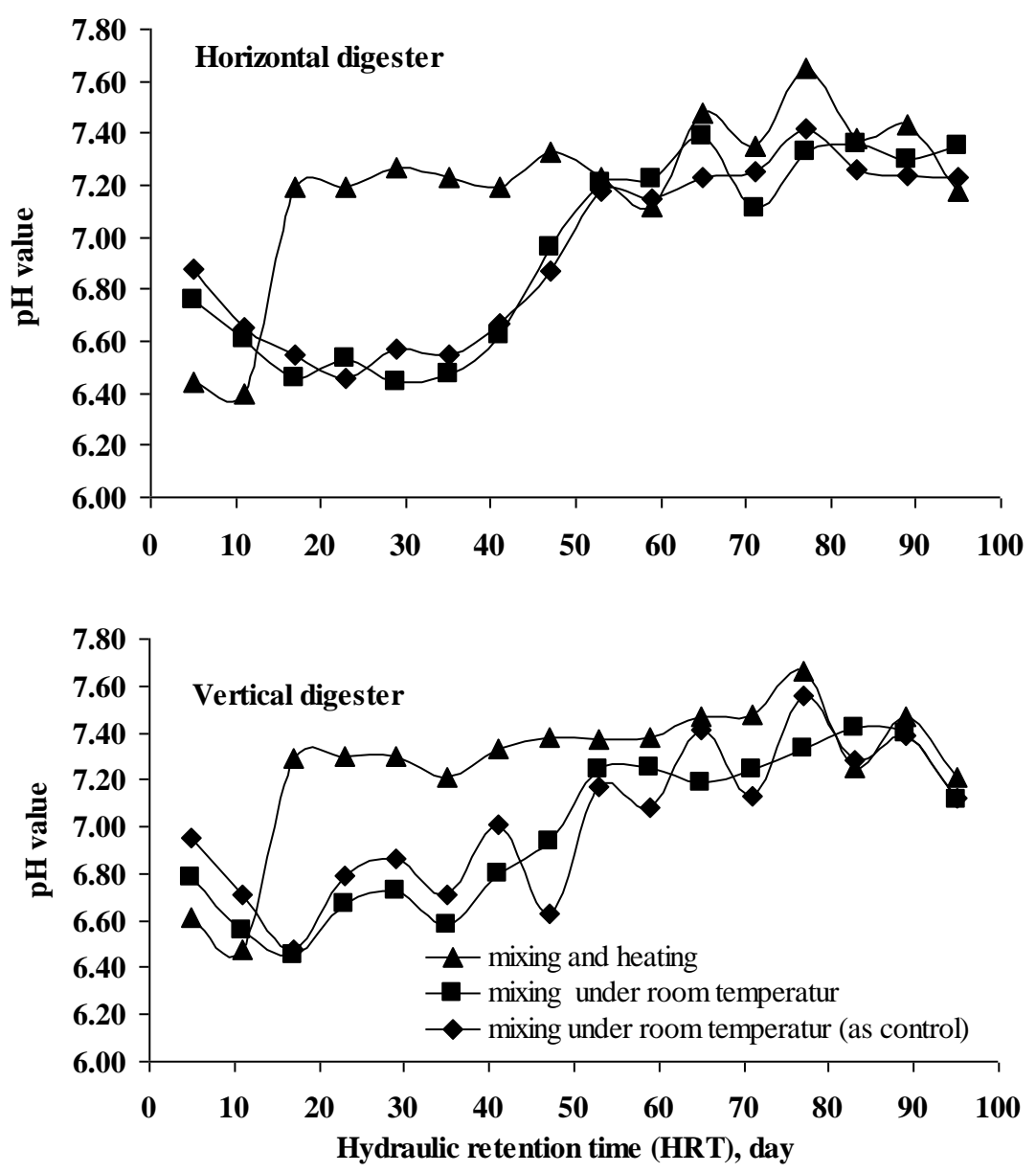

Figure (4): Change in pH values in anaerobically digested buffalo dung as affected by digester shapes and different mixing and heating at different intervals

\subsection{Degradation of organic carbon}

The decomposition of buffalo dung under anaerobic digestion was highly response to temperature level, mixing intensity and digester type. As shown in Fig. (5), the degradation percent of buffalo dung (expressed as organic carbon degradation, \%) was increased in vertical digester compared to horizontal digester with mixing and heating treatments. Similar trend was observed with the mixing treatment under room temperature. On the other hand, under room 
temperature without mixing, the degradation percent was similar in both vertical and horizontal digesters.

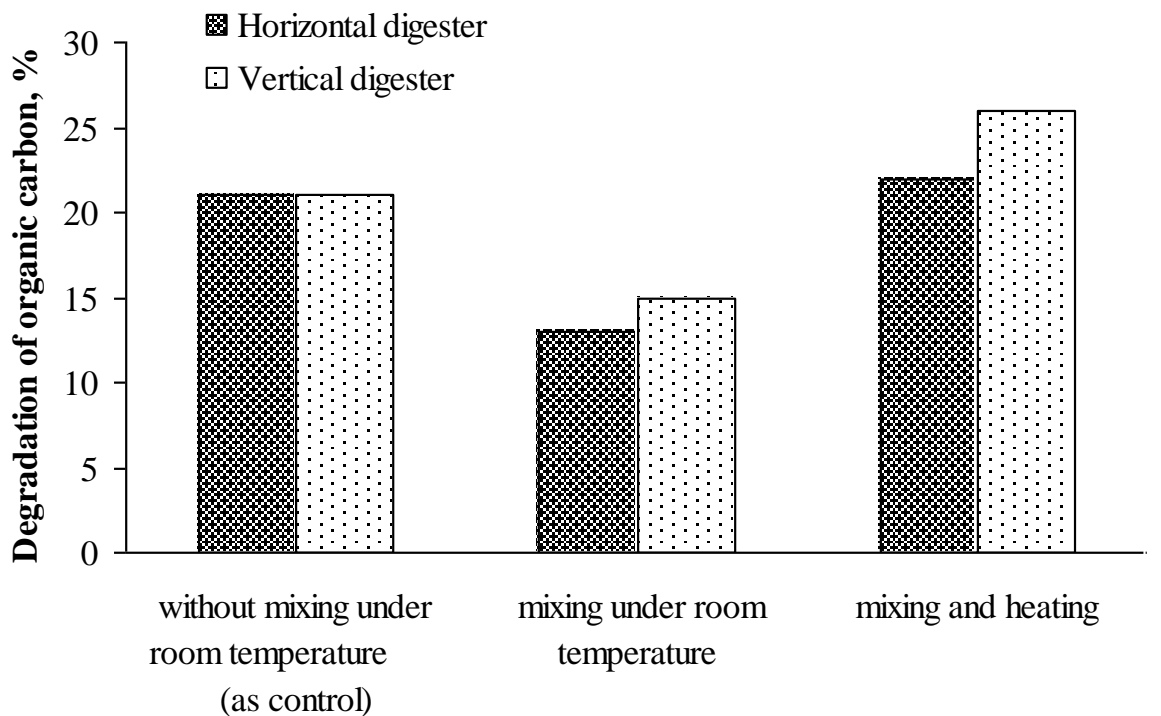

Figure (5): Effect of digester shapes, mixing and heating on organic carbon degradation of buffalo dung.

The $\mathrm{C} / \mathrm{N}$ ratio is used as an index of the decomposition rate, i.e. suitability of organic feeds for methanogenic bacteria. Fig. (6) shows the $\mathrm{C} / \mathrm{N}$ ratio for the different treatments during the hydraulic retention time. 

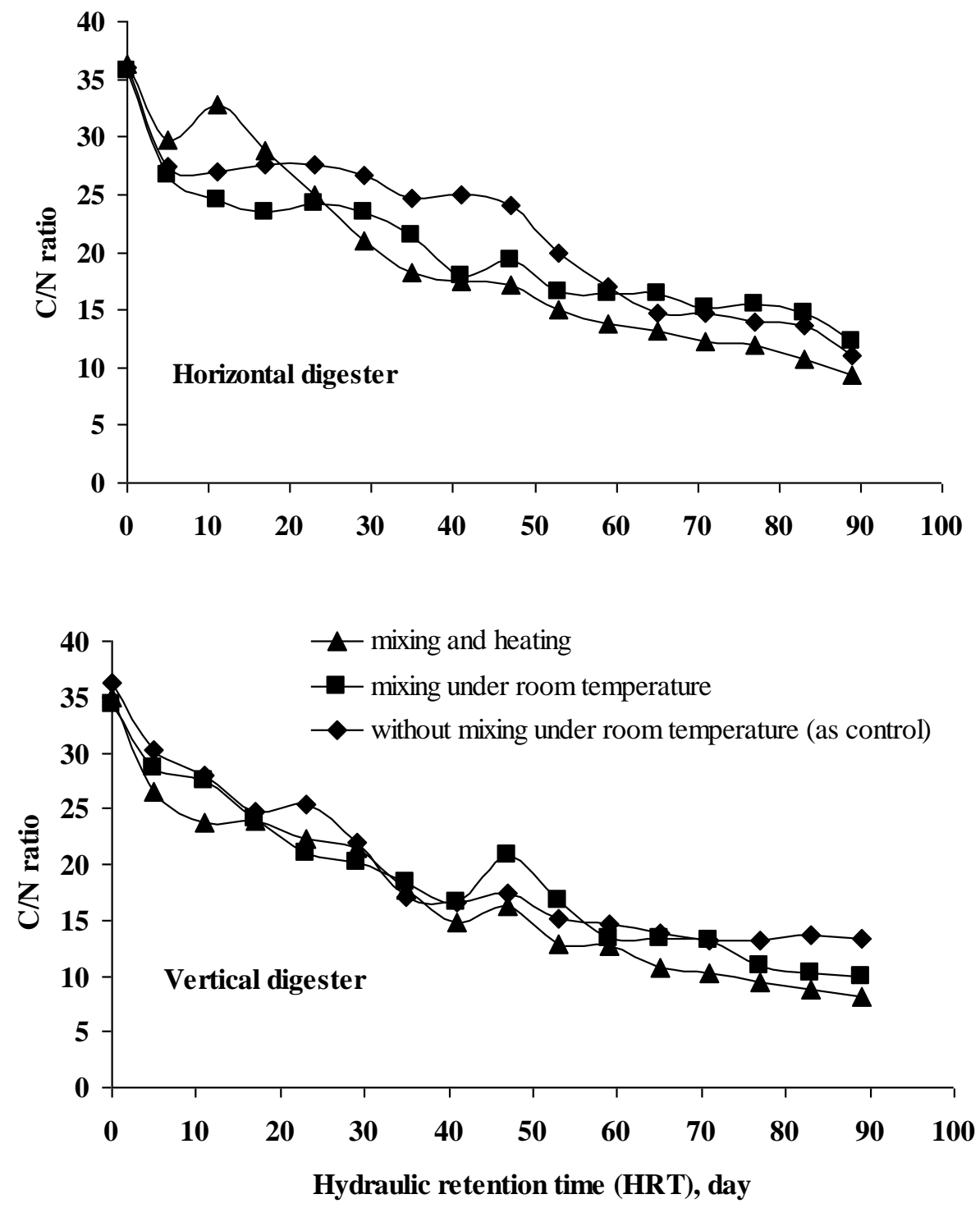

Figure (6): Periodical changes in $\mathrm{C} / \mathrm{N}$ ratio for raw material during anaerobic digestion time course.

The results revealed that there are differences in the declining of $\mathrm{C} / \mathrm{N}$ ratios. Generally, increasing anaerobic digestion period resulted in a highly decreasing in $\mathrm{C} / \mathrm{N}$ ratio in all treatments of buffalo dung material. The lowest $\mathrm{C} / \mathrm{N}$ ratio was recorded in vertical digester with heating and mixing treatments. On the other hand, total nitrogen concentration in 
buffalo dung at different anaerobic digestion was increased from zero day until end of experiment. Total nitrogen ranged from 1.92 to $2.07 \%$ and from 1.66 to $1.83 \%$ in horizontal and vertical digesters, respectively.

As well as, the result indicated that the mixing and heating treatments increase the degradation rate of buffalo dung in both vertical and horizontal digesters through the reduction of OTS as shown in Fig. (7).
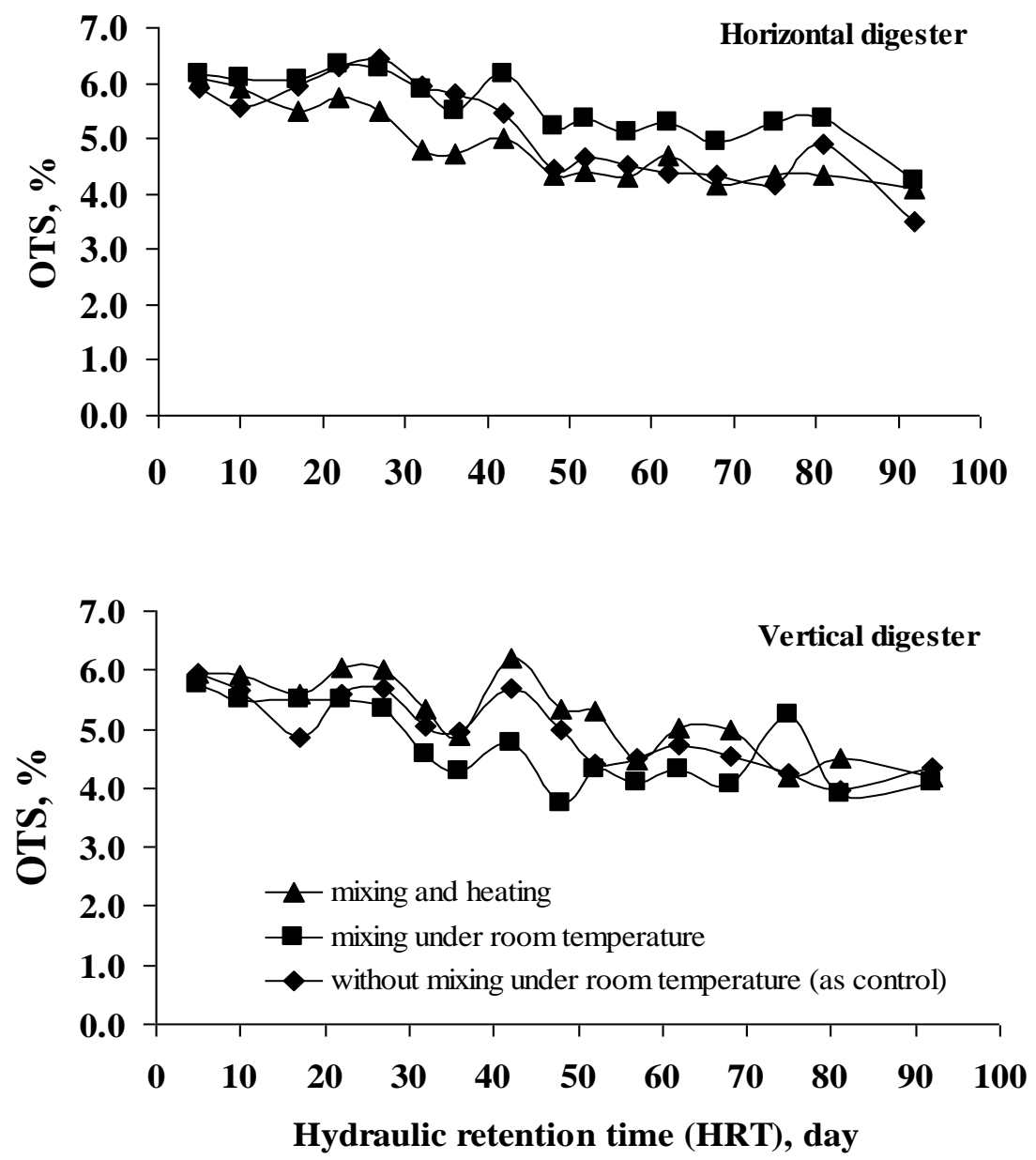

Figure (7): Organic total solids for horizontal and vertical digesters at experimental intervals 
The previous results agree with Iannotti et al., (1993) who found that total carbon content decreased as $\mathrm{CO}_{2}$ evolved while total nitrogen content remained constant. Thus, the decrease in the $\mathrm{C} / \mathrm{N}$ ratio reflected the degradation process during anaerobic digestion. Maximum enhancement in biogas production over the control could be well correlated with maximum reduction in OTS and $\mathrm{C} / \mathrm{N}$ ratio of buffalo dung after 95 days digestion. Demirci and Demirer (2004) using broiler and cattle dung as a substrate for biogas production have reported a similar observation.

Correlation analysis was used in order to evaluate relationships between the biogas and methane production and temperature and $\mathrm{pH}$ at different treatment in this study (Table, 2). Significant correlations were observed between biogas and methane yield and temperature and $\mathrm{pH}$ in case mixing and control in both vertical and horizontal digesters. No significant correlations between biogas yield and temperature and $\mathrm{pH}$ except in mixing and temperature treatment in case vertical digester found correlation between biogas yield and $\mathrm{pH}$. The same trend was record in case methane yield.

Table (2): Significance levels of the correlation between the different treatment and biogas, methane percentage, $\mathrm{pH}$ value and temperature

\begin{tabular}{|c|c|c|c|c|c|c|c|c|c|c|}
\hline \multirow{2}{*}{ 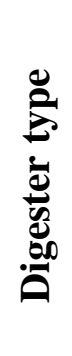 } & \multirow{2}{*}{ 矛 } & \multicolumn{3}{|c|}{$\begin{array}{c}\text { Control } \\
\text { (Without mixing under } \\
\text { room temperature) } \\
\end{array}$} & \multicolumn{3}{|c|}{$\begin{array}{l}\text { (Mixing under room } \\
\text { temperature) }\end{array}$} & \multicolumn{3}{|c|}{ (Mixing and heating) } \\
\hline & & $\begin{array}{c}\text { Biogas } \\
\text { yield, } \\
\text { L/day }\end{array}$ & $\begin{array}{c}\text { Methane, } \\
\%\end{array}$ & $\mathbf{T},{ }^{\circ} \mathbf{C}$ & $\begin{array}{c}\text { Biogas } \\
\text { yield, } \\
\text { L/day }\end{array}$ & $\begin{array}{c}\text { Methane, } \\
\%\end{array}$ & $\mathbf{T},{ }^{\circ} \mathbf{C}$ & $\begin{array}{l}\text { Biogas } \\
\text { yield, } \\
\text { L/day }\end{array}$ & $\begin{array}{c}\text { Methane, } \\
\%\end{array}$ & $\mathbf{T},{ }^{\circ} \mathbf{C}$ \\
\hline 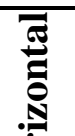 & $\mathbf{T},{ }^{\circ} \mathbf{C}$ & $0.408^{* *}$ & $0.339^{*}$ & - & $0.498^{* *}$ & $0.528^{* *}$ & - & ns & ns & - \\
\hline 음 & pH & $0.531^{* *}$ & $0.671^{* *}$ & $0.732^{* *}$ & $0.753^{* *}$ & $0.851^{* *}$ & $0.722^{* *}$ & ns & $0.382^{*}$ & - \\
\hline 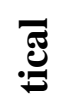 & $\mathbf{T},{ }^{\circ} \mathbf{C}$ & $0.546^{* *}$ & $0.561^{* *}$ & - & $0.641^{* *}$ & NS & - & ns & ns & - \\
\hline$\sum^{ \pm}$ & $\mathbf{p H}$ & $0.589^{* *}$ & $0.657^{* *}$ & $0.714^{* *}$ & $0.798^{* *}$ & $0.401^{*}$ & $0.786^{* *}$ & $0.426^{* *}$ & ns & $\begin{array}{c}0.675^{*} \\
*\end{array}$ \\
\hline
\end{tabular}

* Correlation is significant at the 0.01 level (2-tailed)

Misr J. Ag. Eng., October 2008 
** Correlation is significant at the 0.05 level (2-tailed)

Therefore, we concluded that the amount of biogas produced was depending on not only the type of digester but also the presence of some parameters such as mixing and heating in the digester.

\section{CONCLUSIONS}

\section{The study conducted to the following:}

- The highest biogas yield was observed in vertical digester type $468.1 \mathrm{~L} \mathrm{~kg}^{-1}$ OTS in cases of mixing and heating treatments. Meanwhile, the lowest was $104.7 \mathrm{~L} \mathrm{~kg}^{-1}$ OTS in vertical digester type in cases mixing under room temperature

- The biogas production was positively correlated with the temperature and mixing. The biogas yield $\mathrm{L} \mathrm{kg}^{-1}$ OTS was increased by $106.2 \%$ in cases mixing and heating treatments in horizontal digester type compared to mixing under the room temperature in the same digester type meanwhile, increased by $347.0 \%$ in vertical digester type in the same treatment.

- Effect of digester type, the biogas yield $\mathrm{L} \mathrm{kg}^{-1}$ OTS was increased by $63.7 \%$ in horizontal digester type compared to vertical digester type in treatment without mixing under room temperature meanwhile, increased by $63.5 \%$ in horizontal digester type compared to vertical digester type in treatment mixing under room temperature.

- The biogas production was negative correlated with the mixing under room temperature. The biogas yield $\mathrm{L} \mathrm{kg}^{-1}$ OTS was decreased by $41.6 \%$ in cases mixing under room temperature compared to without mixing under room temperature in horizontal digester type meanwhile, decreased by $41.5 \%$ in vertical digester type in the same treatment.

- Degradation ratio was $21 \%$ in horizontal and vertical digester type in treatment without mixing under room temperature, meanwhile the degradation ratio increased by $10,0 \%$ and $1,, 7 \%$ in vertical digester type compared to horizontal in treatment mixing under room temperature and mixing with heating respectively. 


\section{REFERENCES}

Angelidaki, I. and B. K. Ahring (1994). Anaerobic thermophilic digestion of manure at different ammonia loads: Effect of temperature. Water Res. 28 (3), 727-731.

Bitton, G. (1994). Wastewater Microbiology. Weley-Liss, New York, USA.

Chae, K. J.; Jang, Am; Yim, S. K. and S. Kim (2008). The effects of digestion temperature and temperature shock on the biogas yields from the mesophilic anaerobic digestion of swine manure. Bioresourse Technology, 99:1-6.

Chen, T.; Chynoweth, D. P. and R. Biljetina (1990). Anaerobic digestion of municipal solid waste in a nonmixed solids concentrating digestor. Appl. Biochem. Biotechnol. 24-25, 533-544.

Demirci, G. G. and G. N. Demirer (2004). Effect of initial COD concentration, nutrient addition, temperature and microbial acclimation on anaerobic treatibility of broiler and cattle manure. Bioresource Technol. 93, 109-117.

Deutsche Gesellschaft für Solarenergie e.V., (DGS) (2006). Study on Solar and Biomass Energy Potential and Feasibility in Lao PDR Asia Pro Eco project TH/Asia Pro Eco/05 (101302). International Solar Energy Society, Germany

DEV (1971). Deutsche Einheitesverfahren zur Wasser- und Schlammuntersuchungung. Verlag Chemie, S. 2-6, Weinheim, Germany

Dolfing, J. (1992). The energetic consequences of hydrogen gradients in methanogenic ecosystems. FEMS Microbiol. Ecol. 101, 183-187.

El-Mashad, H. M.; Zeeman, G.; Van Loon, Wilko K. P.; Bot, G. P. A. and G. Lettinga (2004). Effect of temperature and temperature fluctuation on thermophilic anaerobic digestion of cattle manure. Bioresource Technology, 95:191-201.

Erickson, L. E.; Fayet, E.; Kakumanu, B. K. and L. C. Davis (2004). Anaerobic Digestion. National Agricultural Biosecurity Center, Kansas State University

FAO (2001). Production yearbook. Food and Agricultural Organization of the United Nations, Vol. 55 
FAO (2005). Relevance of Biogas Technology to Nepal. SESSION TWO, Consolidated Management Services Nepal, FAO/TCP/NEP/4415-T

Hamdy, Y. A. (1998). The Current Situation of Egyptian Agricultural Wastes. Proceedings of Anaerobic Treatment of Solid Wastes Workshop, 4 may 1998, Mansoura University, Mansoura, Egypt. pp 15 (in Arabic)

Hansen, H. H.; Angelidaki, I. and B. K. Ahring (1999). Improving thermophilic anaerobic digestion of swine manure. Water Res. 33 (8), 1805-1810.

Iannotti, D. A.; Pang, T.; Troth, B. L.; Elwell, D. L.; Keener, H. M. and H. A. J. Hoitink (1993). A quantitative respirometric method for monitoring compost stability. Compost Science and Utilization, 1:5265 .

Kalia, A. K. and S. P. Singh (1998). Horse dung as a partial substitute for cattle dung for operating family-size biogas plants in a hilly region. Bioresource Technology 64 (1998) 63-66. Elsevier Science Ltd. UK

Kaparaju, P.; Buendia, I; Ellegaard, L. and I. Angelidakia (2007). Effects of mixing on methane production during thermophilic anaerobic digestion of manure: Lab-scale and pilot-scale studies. Bioresource Technology

Karim, K.; Hoffmann, R. ; Klasson, K. T. and M. H. Al-Dahhan (2005). Anaerobic digestion of animal waste: effect of mode of mixing. Wat. Res. 39, 3397-3606.

Kayhanian, M. and S. Hardy (1994). The impact of four design parameters on the performance of high-solids anaerobic digestion of municipal solid waste for fuel gas production. Environ. Technol. 15, 557-567.

Kim, I. S.; Kim, D. H. and S. H. Hyun (2002). Effect of particle size and sodium concentration on anaerobic thermophilic food waste digestion. Wat. Sci. Tech. 41, 67-73.

Kivaisi, A. K. and M. Mtila (1998). Production of biogas from water hyacinth (Eichhornia crassipes) (Mart) (Solms) in a two stage bioreactor. World J. Microbiol. Technol. 14, 125-131.

köttner, m. (2003). Integration of biogas technology, organic farming and energy crops. The future of biogas in Europe II, European biogas 
workshop. October 2nd to 4th, 2003,University of Southern Denmark esbjerg / Denmark

Lehtomäki, A.; Huttunen, S. and J. A. Rintala (2007). Laboratory investigations on co-digestion of energy crops and crop residues with cow manure for methane production: Effect of crop to manure ratio. Department of Biological and Environmental Science, University of Jyväskylä, Finland. Conservation and Recycling 51 (2007) 591-609.

Lema, J. M.; Mendez, R.; Iza, J.; Garcia, P. and, F. Fernandez-Polanco (1991). Chemical reactor engineering concepts in design and operation of anaerobic treatment processes. Wat. Sci. Tech. 24, 79-86.

Marchaim, U. (1992). Biogas processes for sustainable development. Food and Agriculture Organization of the United Nations (FAO). Services Bulletin: No 95, 232 p.

Nanda, A. S. and T. Nakao (2003). Role of buffalo in the socioeconomic development of rural Asia: Current status and future prospectus. Animal Science Journal 74, 443-455.

Ndegwa, P. M. and S. A. Thompson (2001). Integrating composting and vermin composting the treatment and bioconversion of biosolids. Biores. Technol. 76: 107-112.

Okeke, C. E. and V. A. Ezekoye (2006). Design, Construction, and Performance Evaluation of Plastic Biodigester. The Pacific Journal of Science and Technology Volume 7. Number 2. November, Nsukka, Nigeria

Reinecke, A. J.; Viljoen, S. A. and R. J. Saayman (1992). The suitability of Eudrilus eugeniae, Perionyx excavatus and Eisenia foetida (Oligochaeta) for vermicomposting in Southern Africa in terms of their temperature requirements. - Soil Biol. Biochem. 24: 1295-1307.

Rofiqul, I. M; Rabiul, I. M and A. M. Rafiqul (2006). Renewable energy resources and technologies practice in Bangladesh, Renewable and Sustainable Energy Reviews, doi:10.1016/j.rser.

Shilpkar, P.; Shah, M. and D. R. Chaudhary (2007). An alternate use of Calotropis gigantea: Biomethanation. Current Science, VOL. 92, NO. $4,435-437 \mathrm{pp}$ 
Smith, L. C; Elliot, D. J. and A. James (1996). Mixing in upflow anaerobic filters and its influence on performance and scaleup. Water Res. 30, 3061-3073.

Stroot, P. G.; McMahon, K. D.; Mackie, R. I. and L. Raskin (2001). Anaerobic codigestion of municipal solid waste and biosolids under various mixing conditions-I. Digester performance. Water Res. 35, 1804-1816.

Van Haandel, A. and G. Lettinga (1994). Anaerobic Sewage Treatment- A Practical Guide for Regions with Hot Climate. John Wiley \& Sons. Chichester, UK

Vandeviviere, P.; De Baere, L. and W. Verstraete (2002). Types of anaerobic digester for solid wastes. In J. Mata-Alvarez (Ed), Biomethanization of the organic fraction of municipal solid wastes (pp. 111-137). London: IWA Publishing.

Vavilin, V. A. and I. Angelidaki (2005). Anaerobic degradation of solid material: Importance of initiation centers for methanogenesis, mixing intensity, and 2D distributed model. Biotechnol. Bioeng. 89 (1), 13122.

Vedrenne, F.; Beline, F.; Dabert, P. and N. Bernet (2007). The effect of incubation conditions on the laboratory measurement of the methane producing capacity of livestock wastes. (in press). Bioresour. Technol. DOI:10.1016/j.biortech.2006.11. 043.

Viesturs, U.; Teliseva, G.; Dobele, G. and T. Dizbite (1995). Energy production from biomass: World experience. Proceedings of the Latvian Academy of Science. Section B, No 9/10 (578/579), The Latvian Academy of Science, Latvia (pp97-112).

Wittmaier, M. (2003). Co-fermentation of organic substrates in the decentralized production of regenerative energy .Workshop, "Technologies of Municipal Waste Treatment- Experiences and Challenges", Hanoi Uni. Sc., Vietnam. 


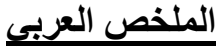

\section{تأثثير التدفئة والتقليب و نوع المخمر على إنتاج الغاز الحيوي من روثِ الجاموسِ المثر}

\section{د. محمد علي عبد الهادي' د. سامي عبد الملك محمد عبد العظيم}

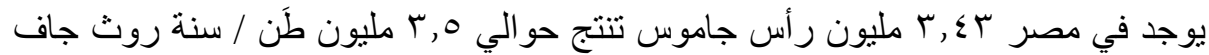

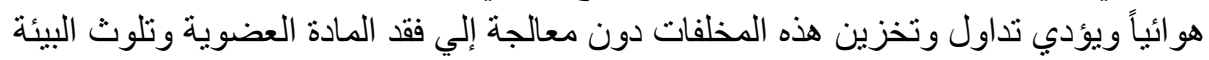

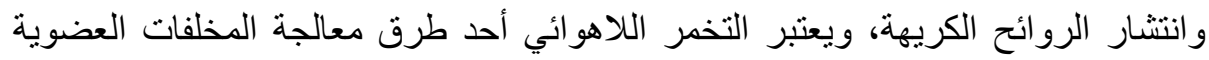

$$
\text { لإلتاج الغاز الحيوي (البيوجاز). }
$$

أجريت دراسة معملية علي روث الجاموس بالوحدة التجريبية للغاز الحيوي بقسم الهندسة الزراعية ـ كلية الزراعة ـ جامعة قناة السويس في ستة مخمرات (تلاثة مخمرات التهات أفقية

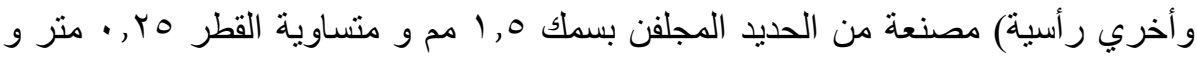

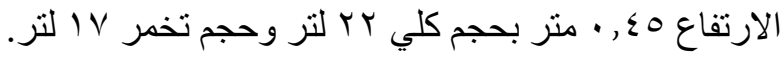
تم تغذية المخمرات بمخلفات الجاموس بنسبة r, ؟٪٪ مادة جافة عضوية نظام تغذية مرة

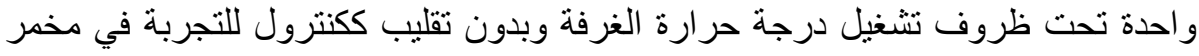

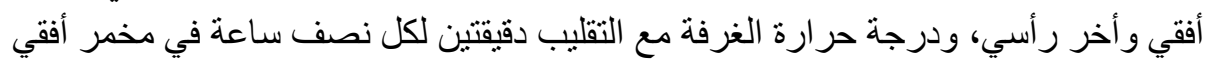

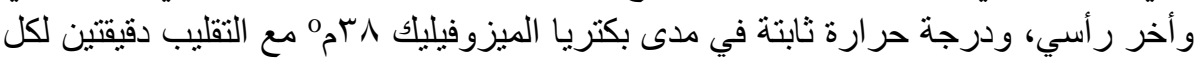
نصف ساعة في مخمر أفقي وأخر رأسي.

تم تقدير النسبة المئوية للمادة الجافة العضوية OTS معملياً في المادة المتخمرة لروثي

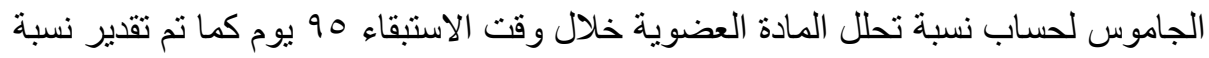

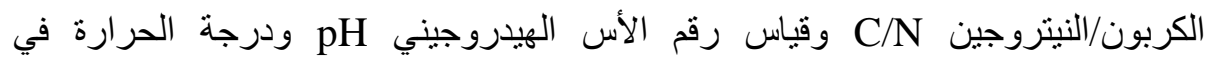

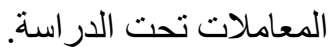
تم قياس كمية الغاز الحيوي ونسبة الميثان اليومية المتحصل عليها للمعاملات المختلفة ونم حساب كمية الغاز الحيوي و الميثان باللتر المتحصل عليهان الئه من كل واحد كيلو جرام مادة عضوية جافة.

1- مدرس بقسم الهندسة الزر اعية ـ كلية الزر اعة ـ - جامعة قناة السويس

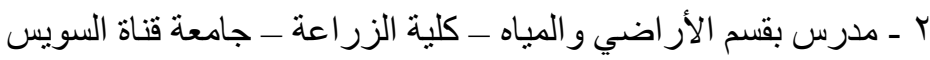




\section{وقد توصلت الار اسة إلى النتائج التالية:}

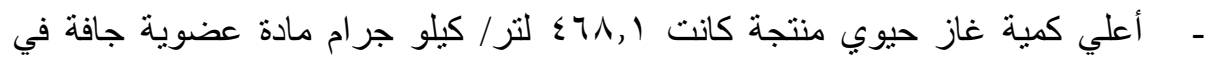

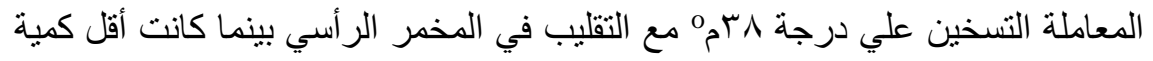

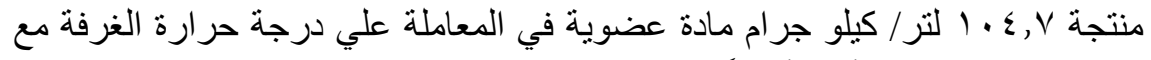
التقليب في المخمر الر أسي أيضاً.

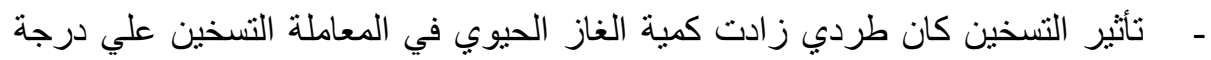

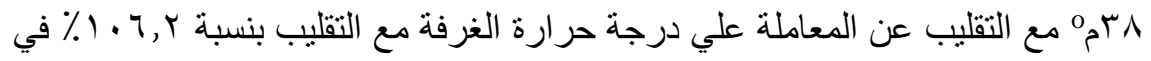

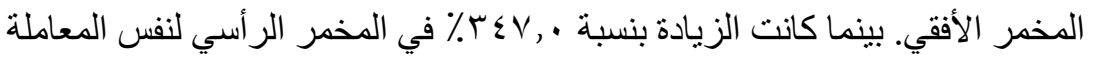

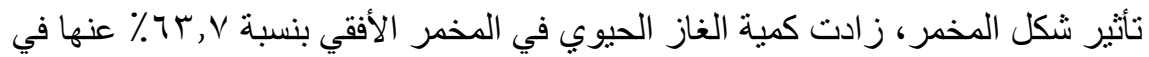

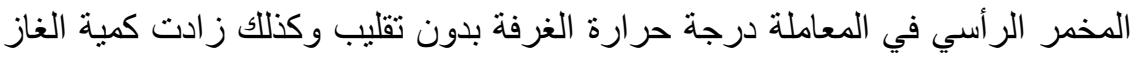

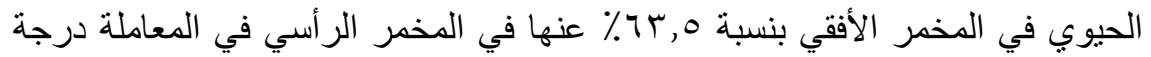

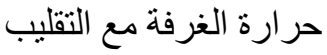
- - تأثير التقليب كان عكسي قلت كمية الغاز الحيوي في المعاملة التقليب علي درجة حرارة الغرفة عن المعاملة بدون تقليب علي درجة حرارة الغرفة في المخمر الأفقي بنسبة

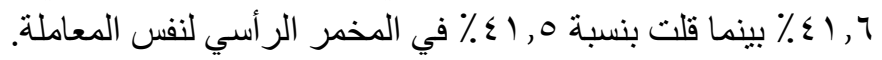

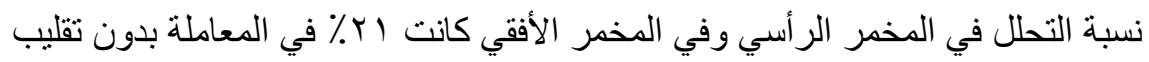

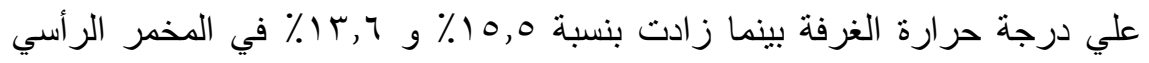

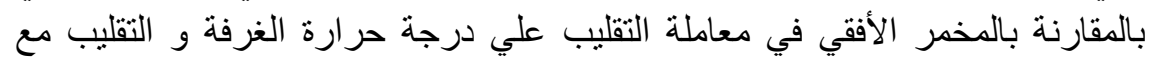

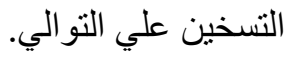

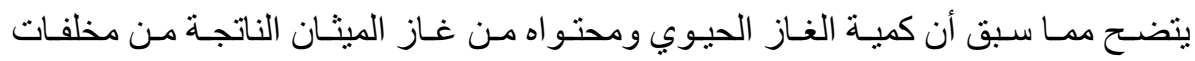

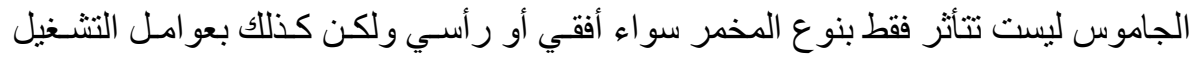

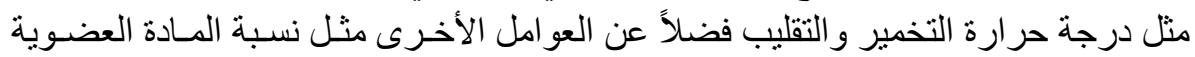
الجافة، نسبة الكربون/النيتروجين C/N ورقم الأس الهيدروجيني pH في المادة المتخمرة. 